Article

\title{
Selection of Representative General Circulation Models for Climate Change Study Using Advanced Envelope-Based and Past Performance Approach on Transboundary River Basin, a Case of Upper Blue Nile Basin, Ethiopia
}

\author{
Hailu Wondmageghu Tenfie ${ }^{1,2, *}$, Fokke Saathoff $^{1}$ (D), Dereje Hailu ${ }^{3}$ and Alemayehu Gebissa ${ }^{1}$ \\ 1 Faculty of Agricultural and Environmental Sciences, Geotechnics and Coastal Engineering, Rostock \\ University, 18051 Rostock, Germany; fokke.saathoff@uni-rostock.de (F.S.); \\ alemayehu.gebissa@uni-rostock.de (A.G.) \\ 2 School of Civil, Water Resource \& Architecture, Kombolcha Institute of Technology, Wollo University, \\ Kombolcha 1145, Ethiopia \\ 3 School of Civil and Environmental Engineering, Institute of Technology, Addis Ababa University, \\ Addis Ababa 1176, Ethiopia; dhasfaw@gmail.com or dereje.hailu@aait.edu.et \\ * Correspondence: w.hailu@yahoo.com or hailu.tenfie@uni-rostock.de; Tel.: +49-151-5749-6858
}

Citation: Tenfie, H.W.; Saathoff, F.; Hailu, D.; Gebissa, A. Selection of Representative General Circulation Models for Climate Change Study Using Advanced Envelope-Based and Past Performance Approach on Transboundary River Basin, a Case of Upper Blue Nile Basin, Ethiopia. Sustainability 2022, 14, 2140.

https: / /doi.org/10.3390/

su14042140

Academic Editors: Giuseppe Barbaro and Luigi Aldieri

Received: 24 December 2021

Accepted: 2 February 2022

Published: 13 February 2022

Publisher's Note: MDPI stays neutral with regard to jurisdictional claims in published maps and institutional affiliations.

Copyright: (C) 2022 by the authors. Licensee MDPI, Basel, Switzerland. This article is an open access article distributed under the terms and conditions of the Creative Commons Attribution (CC BY) license (https:// creativecommons.org/licenses/by/ $4.0 /)$.

\begin{abstract}
For the selection of global climate models in the upper basin of the Blue Nile, an advanced envelope-based approach was used. Currently, the number of general circulations models (GCM) has increased extremely. The reliability of any general circulation model in a particular region is confronted, so the selection of the appropriate climate models that can predict the climate variable is essential. Representative concentration pathways RCP4.5 and RCP8.5 were taken into account. For RCP4.5 105 GCMs were used and for RCP8.5 78 GCMs were used to select the best performance models for the Upper Blue Nile Basin for a climate change impact study. Three steps were followed to derive the best performing models in the study area based on their range of projected mean temperature and precipitation changes, the range of projected extreme changes, and the ability to reproduce past climates between 1971 and 2000 and 2071-2100. Five corners of the spectrum were used, e.g., wet-warm, wet-cold, dry-warm, dry-cold, and the 50th percentile of the temperatures. For RCP4.5 and RCP8.5, a total of 25 GCMs were chosen based on the range of anticipated mean temperature and rainfall change. Based on the range of extreme changes, 10 GCMs were chosen. Finally, for each RCP4.5 and RCP8.5, five GCMs were chosen by combining all three stages.
\end{abstract}

Keywords: climate change; GCM; CMIP5; climate model selection; Upper Blue Nile River Basin

\section{Introduction}

Climate models are useful tools for understanding and predicting the complex climate of the Earth. Forty GCMs from twenty research groups took part in phase 5 of the Coupled Model Intercomparison Project (CMIP5) [1]. Every climate model created does not have the same predictive performance in a specific area. For water resource planning, it is essential to define acceptable GCMs for a given area. Climate change scenarios with different rates and magnitudes provide a framework for assessing the likelihood of exceeding identifiable physical change thresholds and the effects on biological and human systems [2]. Representative concentration pathways (RCPs) scenarios that include time series of total greenhouse gas (GHG), aerosol and chemically active gas (GHG) emissions and concentrations, and land use/land cover [3]. Planners and decision-makers have traditionally utilized scenarios to examine situations with uncertain outcomes [4]. The Intergovernmental Panel on Climate Change (IPCC) Fifth Assessment Report (AR5) suggests four trajectories for future climate change analysis: RCP8.5, RCP6, RCP4.5, and RCP2.6 [5]. While the size 
and number of climate models is growing, computing power is low. Hence, it is imperative to compromise the amount that can be used for an analysis of climate change. In most climate impact studies, climate models should be selected based on the full range of changes. There is no easy way to choose climate models [6]. The selection of climate downscaling models is typically carried out in two key ways, namely, the envelope and the past efficiency approach [7-9]. In the output approach above, the choice of climate models is based on the ability of the models to duplicate the continuous climate, while the envelope approach [10] takes into account the range of models that cover a large number of predictions. The performance approach has the possibility to hide all projection areas selected from the available GCM pool for an ensemble, eliminating the need to use the envelope method after selection. Other methods for selecting the best climate model are the applied filter and wrapper feature selection methods $[6,11-13]$ taking into account different qualification metrics, statistical indices or their combination using multi-criteria decision analysis (MCDA), while past performance and envelope-based are used on this study. The study relies on climate models' ability to replicate past weather circumstances, or on improvements to the broad spectrum of climatic variables planned from the entire collection of accessible climate models. The envelope and past performance approach were applied to the Indus, Ganges, and Brahmaputra river basins [6]. The following procedures were chosen for the selection of climate models that have the optimal projection over the examination field: (1) climate models based on the magnitude of anticipated changes in weather patterns; (2) based on a variety of extreme climatic variable changes; and (3) based on weather simulation capabilities to reproduce past climate variables. Based on the 5th Assessment Report of the IPCC, the selected climate model data will be downscaled and used as input in the hydrological SWAT model $[14,15]$ in order to measure potential impacts of climate change on river runoff and sediment yield in the Upper Blue Nile River Basin.

\section{Data Sources and Study Area}

\subsection{Study Area}

The current study employed procedure of climate change model selection for the Upper Blue Nile River Basin, which contributes significantly to flow and sediment and is the source of more than $60 \%$ of the Nile River [15] and also located between longitude $32^{\circ} \mathrm{E}$ and $40^{\circ} \mathrm{E}$ and latitudes $9^{\circ} \mathrm{N}$ and $16^{\circ} \mathrm{N}$ [16] (Figure 1).The climate in the Abay/Upper Blue Nile River Basin is governed by the migration of the Inter Tropical Convergent Zone (ITCZ), which moves seasonally from the South to the North and back [17,18]. The Blue Nile's discharge is highly seasonal, with over $80 \%$ of annual runoff falling between July and October, and only 4\% dropping between January and April [19]. The precipitation is also highly fluctuating and influenced by the tropical highland monsoon. It has a rainy season from June to September, a short rainy season from March to May, and a dry season from October to May [20-22]. 


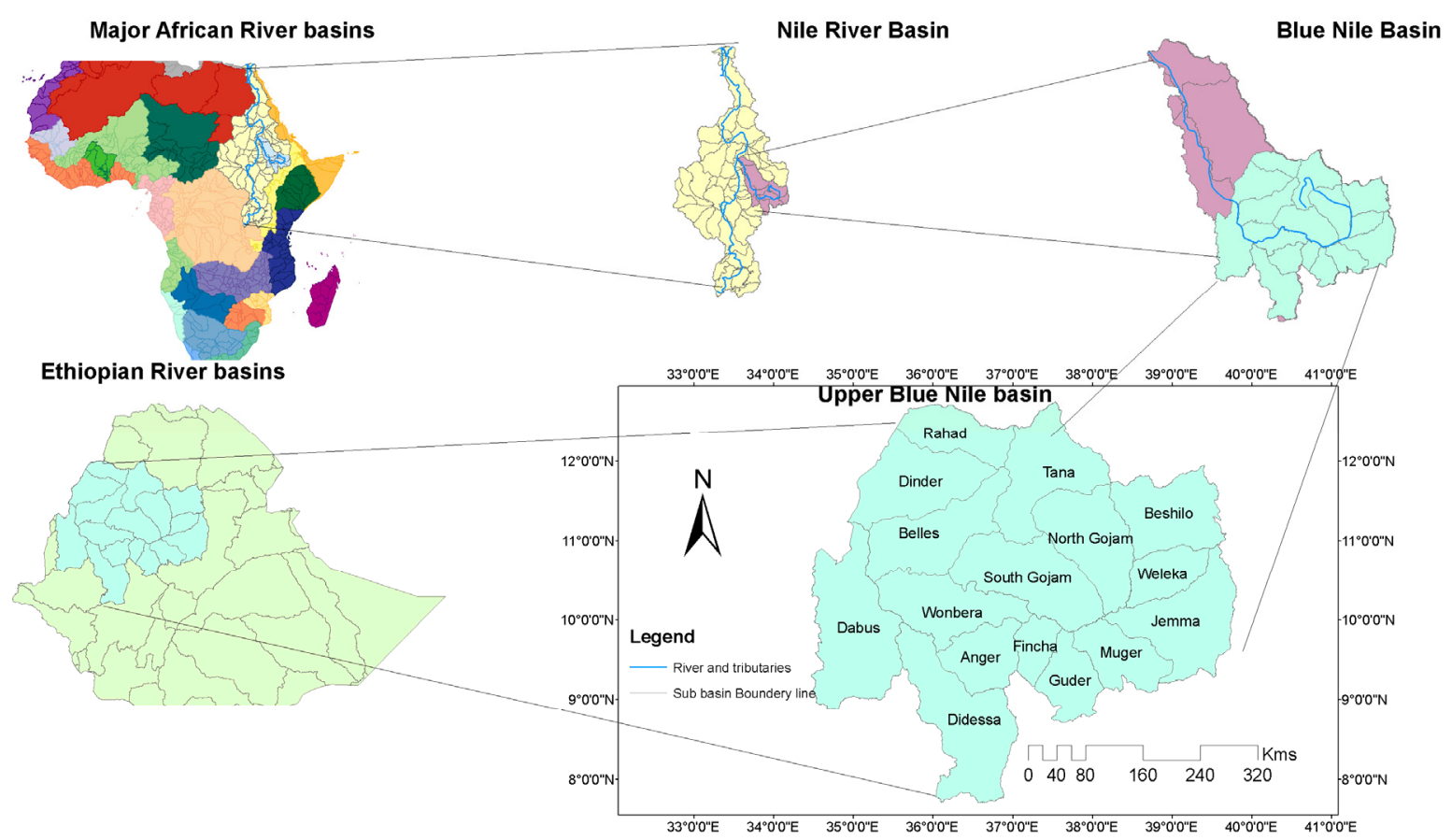

Figure 1. Upper Blue Nile Basin (UBNB): main catchments, streams, and tributaries.

\subsection{Data Collection and Sources}

Three types of data were used: general circulation model (GCM) output of precipitation and mean air temperature, extreme indices, and the Water and Global Change (WATCH) Forcing Data ERA-Interim (WFDEI) are the data sets used for this study.

\subsubsection{GCM Outputs}

The Climate Modeling Association has established a set of four new representative concentration trajectories as a foundation for long-term and short-term modeling studies [3]. The 5th IPCC assessment suggested two medium stability scenarios (RCP4.5 and RCP6), a scenario with very high base emissions (RCP8.5), and a mitigated scenario (RCP2.6). A medium (RCP4.5) and a high (RCP8.5) emission scenario were chosen for this study as longterm climate change models do not provide for changes in vegetation. The change in temperature and precipitation simulated by Coupled Model Intercomparison Project 5 (CMIP5) GCMs between the historical periods 1971-2000 and 2071-2100 was obtained from the environment explorer scenario (https: / / climexp.knmi.nl/start.cgi) (accessed on 15 June 2021) of the Royal Netherlands Metrological Institute (KNMI) for the representative concentration pathway, RCP4.5, and RCP8.5 radiative forcing scenarios.

\subsubsection{Extreme Indices}

The extremes indices from the Expert Team on Climate Change Detection and Indices ETCCDI archive $[23,24]$ provided by the "Canadian Centre for Climate Modeling and Analysis" was utilized to obtaisn the annual extremes of the regular CMIP5 results. This information was collected and downloaded in an indirect manner via the KNMI Climate Explorer, a web-based analysis utility for investigating change in climate.

\subsubsection{Observed Data}

The data set WATCH Forcing Data methodology applied to ERA-Interim (WFDEI [25,26] was used to test the model output of individual GCM runs. It was created by means of the same approach as the frequently used WATCH Forcing Data [27] using the ERA interim reanalysis data [24]. We used WFDEI precipitation data that had been corrected for Global Precipitation Climatology Center (GPCC) precipitation data [28]. 


\section{Materials and Method}

The envelope-based technique and the prior performance technique are combined in a three-stage selection approach for GCM runs. To begin, climate models are chosen for their capacity to predict yearly average variations in mean total temperature and precipitation. After that, the range is fine-tuned based on rainfall and temperature extremes. Finally, the final editions of the remaining models are compared to the WFDE [25] climate reference product to arrive at a decision.

\subsection{Representative Concentration Pathways Selection}

Climate scenarios are hypothetical scenarios used to assess how climate change would affect infrastructure and ecosystems [29]. In its fifth assessment report, the Intergovernmental Panel on Climate Change (IPCC) proposed four new scenarios known as Representative Concentration Pathways [30].

With one mitigation scenario (RCP2.6), two intermediate stabilization scenarios (RCP4.5/RCP6), and one very high baseline emission scenario (RCP4.5/RCP6), the four RCPs chosen are judged scientifically representative (RCP8.5) [3]. By 2100, the Rising Radiative Forcing Pathway (RCP8.5) would have reached $8.5 \mathrm{~W} / \mathrm{m}^{2}(1370 \mathrm{ppm} \mathrm{CO}$ equivalent) $[3,31]$. RCP6 slimits the stabilization without overshoot pathway to $6 \mathrm{~W} / \mathrm{m}^{2}(850 \mathrm{ppm}$ $\mathrm{CO}_{2}$ eq.) after 2100. After 2100, RCP4.5 stabilizes without overshooting to $4.5 \mathrm{~W} / \mathrm{m}^{2}$ (650 ppm $\mathrm{CO}_{2}$ eq.) [32]. RCP2.6 has a radiative forcing peak of $3 \mathrm{~W} / \mathrm{m}^{2}\left(490 \mathrm{ppm} \mathrm{CO}_{2}\right.$ eq.) prior to 2100 , then drops to $2.6 \mathrm{~W} / \mathrm{m}^{2}$ by 2100 (the chosen pathway). RCP2.6 reflects the lower end of the scenario in terms of emissions and radiative forcing [33]. In the second part of the twenty-first century, these scenarios commonly portray negative emissions from energy use. The scenario appears technically feasible, but one critical assumption is that all countries will contribute in the short term, which includes expanding participation beyond Countries of the Organization for Economic Cooperation and Development (OECD) and involving key OECD countries [34]. We decided not to include RCP2.6 in the climate model ensemble because adaptation planning requires robust, representative climate change scenarios. This means there are two medium stabilization scenarios (RCP4.5 and RCP6) to choose from, as well as one with extremely high baseline emissions (RCP8.5). In this case, combining RCP4.5 and RCP8.5, which comprise a medium stability scenario and a high emission scenario while spanning the entire range of radiative forcing triggered by RCP4.5, RCP6, and RCP8.5 is the optimum option. Despite the fact that we only used RCP4.5 and RCP8.5 to create ensembles, the method presented here can easily be adapted to other RCPs.

\subsection{Climatic Means Changes}

The initial decision is based on a set of estimates of mean air temperature (T) and total annual precipitation sum $(\mathrm{P})$ increases from 1971 to 2100, dispersed in the model domain between longitude $32^{\circ} \mathrm{E}$ and $40^{\circ} \mathrm{E}$ and latitudes $7^{\circ} \mathrm{N}$ and $13^{\circ} \mathrm{N}$. The $105 \mathrm{CMIP} 5$ General Circulation models (GCM) for RCP4.5 and 78 for RCP8.5 for change in temperature and precipitation were calculated. The Climate Explorer (http:/ / climexp.knmi.nl) (accessed on 15 June 2021) of the Royal Netherlands Meteorological Institute (KNMI) was used to make this measurement. The 10th and 90th percentile values for $\Delta \mathrm{T}$ and $\Delta \mathrm{P}$ are measured. All the model runs were used in RCP4.5 and RCP8.5 independently after resampling the GCM data to the same $2.5^{\circ} \times 2.5^{\circ}$ grid. Creation of scenarios data inputs for impacts modeling, assessment of the effects in relation to the current environment, and discussion of effective adaptation responses are all common uses of downscaling. Significant uncertainties associated with climate model scenarios typically cascade into even greater uncertainties in regional climate change scenarios and impacts [35]. The complete range of GCM projections is wide and extended when downscaled or turned into possible impacts, with high uncertainties attached $[35,36]$ and it cascades to an even broader spectrum. The models can also be classified as reflecting the Warm-Wet, Warm-Dry, Cold-Wet, and Cold-Dry corners of the full spectrum, as well as projections that are around the median 
tendency of future model projections, since the available future predictions range from extremely wet to extremely dry future climates, or from extremely warm to extremely cold future climates. These figures represent the four extremes of predicted temperature and precipitation variations. Both the tenth percentile value for $\Delta \mathrm{T}$ and the tenth percentile value for $\Delta \mathrm{P}$ are classified as 'cold and dry'. The 'cold, wet' corner of the continuum is represented by the 10th percentile value for $\Delta \mathrm{T}$ and the 90 th percentile value for $\Delta \mathrm{P}$. The 90th percentile value for $\Delta \mathrm{T}$ and the 10th percentile value for $\Delta \mathrm{P}$ both fall into the 'warm,

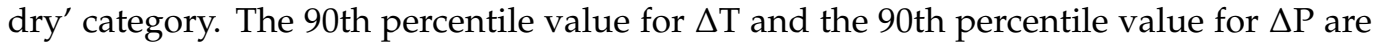
both in the 'warm, wet' category. The 10th and 90th percentile values are used in place of the minimum and maximum projections to avoid the collection of outliers [37,38]. The model runs' proximity to the 10th and 90th percentile values is calculated using percentile rank scores corresponding to the model runs' projections for $\Delta \mathrm{T}$ and $\Delta \mathrm{P}$ in relation to the whole range of forecasts in the complete ensemble [6]:

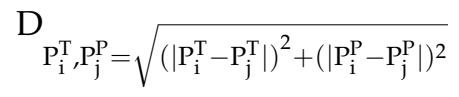

where $D_{P_{i}^{T}, P_{j}^{P}}$ is the distance of a model $(j)^{\prime} s \Delta T$ and $\Delta P\left(P_{i}^{T}\right.$ and $P_{j}^{P}$, respectively), to the corner's (i)'s 10th and/or 90th percentile of $\Delta \mathrm{T}$ and $\Delta \mathrm{P}$ score for the entire ensemble $\left(\mathrm{P}_{\mathrm{i}}^{\mathrm{T}}\right.$ and $\mathrm{P}_{\mathrm{j}}^{\mathrm{P}}$, respectively). For each corner, the five models with the lowest $\mathrm{D}$ values and data available for a regular time phase are chosen from the ensemble. Since the GCM runs will be downscaled, only models that contain data for a daily time step are chosen. Model runs with data only available in bigger time increments are integrated in the initial pool of available model runs, which are used to measure the percentile values of the model runs, in order to acquire a complete picture of all anticipated probable futures. Each RCP has its own RCP. The first selection yields five model runs for each RCP. All ensemble members are implemented in the ensemble that goes through the initial selection step for GCMs with available ensemble members of various initial conditions (denoted by rxixpx after the GCM's name). If all ensemble members of the initial criteria are used, The 10th and 90th percentile values are described differently if all ensemble members of the original criterion are utilized per GCM than if only one ensemble member of the initial criteria is employed. We decided to encompass all ensemble members with an initial condition, as each one contributes to a different result and there is no way of knowing which one should be preferred over the others.

\subsection{Refined Selection: Changes in Climatic Extremes}

Extreme climatic events and changes are particularly important because of their potentially devastating effects on humanity and ecosystems, as highlighted by the Intergovernmental Panel on Climate Change's Special Report on Extreme Events (SREX) [39]. After the initial screening process, the number of Models left is further lowered. The model runs are evaluated for their expected changes in climatic extremes in this phase. Changes in two Expert Team on Climate Change Detection and Indices (ETCCDI) indices for air temperature and precipitation are used to measure changes in climatic extremes. Variations in the Warm Spell Duration Index (WSDI) and the Cold Spell Duration Index (CSDI) are investigated to describe changes in air temperature extremes. Since the climate model ensemble will be used to force hydrological and agricultural growth models, we decided to look at variations in R99pTOT and CDD as evident indices of precipitation extremes leading to corresponding hydrological extremes. WSDI is a useful indicator for instances when crops may be subjected to water stress due to increased evapotranspiration during hot spells, but CDD is a good indicator for crop growth during dry spells. The indices are calculated for each of the $2.5^{\circ} \times 2.5^{\circ}$ grid cells in the research region using regular model performance for each year in the future era (2071-2100) and the reference period (1971-2000). The most appropriate index for air temperature and the most important indicator for precipitation are taken into account for each model chosen in the first selection. 
For example, the models in the warm, wet corner use WSDI, which shows warm periods, and R99pTOT, which shows extreme precipitation events. In this case CDD and CSDI are ignored, but the dry and cold corners are considered for models in the two related indices are both rated and given a score of 1-5 for the five models originally selected for each corner. Likewise, the model with the highest WSDI increase gets five points, while the model with the lowest WSDI increase gets one Point. To arrive at a final result, all points are added together. The models with the highest final scores are selected based on their final score. This reduces the number of models for each corner from five to one. For each RCP, four corners $\mathrm{x}$ two models equals eight models that are validated against the climatic reference product.The description of extreme indices used in this study is depicted in Table 1.

Table 1. Extreme indices used during the GCM selection method. Tables should be placed in the main text near to the first time they are cited.

\begin{tabular}{ccc}
\hline Climate Variable & ETCCDI Index & Description of the ETCCDI Index \\
\hline Precipitation & $\begin{array}{c}\text { R99pTOT } \\
\text { CDD }\end{array}$ & $\begin{array}{c}\text { Precipitation as a result of exceptionally wet days }(>99 \text { th percentile) } \\
\text { Maximum length of a dry spell }(\mathrm{P}<1 \text { mm): consecutive dry days }\end{array}$ \\
Air Temperature & WSDI & $\begin{array}{l}\text { Warm spell duration index: the number of days in a period of at least } \\
\text { six days where the daily maximum temperature (TX) is greater than } \\
\text { the 90th percentile. }\end{array}$ \\
Cons & $\begin{array}{l}\text { Cold spell duration index: the number of days in a period of at least } \\
\text { six days where the daily minimum temperature (TN) is less than in } \\
\text { the tenth percentile. }\end{array}$ \\
\hline
\end{tabular}

In the preceding steps, the precipitation skill score of the screened models was calculated using the mean temperature change and the annual sum of the precipitation and extreme indices, between the group that received the maximum weighted rank skill value of 1 and the others obtained a rank based on their difference to this highest calculated using Equation (2).

$$
S K_{E I}=1-\frac{E I_{h}-E I_{t}}{E I_{h}}
$$

$S K$ denotes the weighted ran for the particular extreme index. EI denotes the maximum index value in a group, $h$ denotes the highest index value in a group, and $t$ denotes the target index to be classified. Similarly, when the means were changed that is $\Delta \mathrm{T}\left({ }^{\circ} \mathrm{C}\right)$ and $\Delta \mathrm{P}(\%)$, the ranking $\left(S K_{m}\right)$ was established based on the difference $\Delta \mathrm{T}\left({ }^{\circ} \mathrm{C}\right)$ or $\Delta \mathrm{P}(\%)$ exposed by each member with the percentile became relevant value for this group.

$$
S K_{m}=1-\frac{(\Delta \mathrm{T} \text { or } \Delta \mathrm{P})_{10,50 \text { or } 90^{\text {th }} \text { percentile }}-(\Delta \mathrm{T} \text { or } \Delta \mathrm{P})_{\text {target }}}{(\Delta \mathrm{T} \text { or } \Delta \mathrm{P})_{10,50 \text { or } 90^{\text {th }} \text { percentile }}}
$$

\subsection{Past Performance}

The initial decision focuses on a series of projections of mean air temperature $(\Delta T)$ and total annual precipitation sum $(\Delta \mathrm{P})$ changes for the period.

After the refined range, the remaining models are validated against the WFDEI data set [26]. The qualification score covers the years 1980 to 2004, and skill scores for each model are calculated using all monthly values from the 25 -year data set. The ability of each model to simulate the reference climate is determined by comparing monthly mean air temperature and monthly rainfall totals between the model simulation and the WFDEI. In order to analyze variations in the model performance between different river basins and between the upstream and downstream sections of the basins, a validation is carried out for each sub-basin (Figure 1) in order to prevent overestimation and underestimation in the entire area.

Refs. [40-42] developed skill ratings to measure the efficiency of the selected GCM runs. Temperature and precipitation capabilities are calculated differently. The method [40] is used 
to calculate the temperature skill ranking. The least cumulative value of two distributions of each binned value was calculated to produce a metric that quantifies the common area between two probability distribution function PDFs. This temperature Skill Score was calculated using Equation (4):

$$
S K_{T m p}=\sum_{1}^{n} \operatorname{minimum}\left(Z_{G C M}, Z_{o b s}\right)
$$

The number of bins used to calculate the PDF is represented by $n$. The frequency of values in a given bin from the model is represented by $Z_{G C M}$, while $Z_{O b s}$ represents the frequency of values in a given container/bin from the observed data. This skill is given a 1 if the simulated and observed data are identical, and a 0 if there are no similarities at all. In this study, 100 bins were used to generate the PDFs. The precipitation ability score is based on [41]; it is made up of a series of five skill score functions that account for different characteristics of precipitation behavior. These skill score functions are described below for our case of comparing GCM data to the WFDEI dataset: these are the five skill score functions for a specific model j:

$$
\begin{aligned}
& \mathrm{f}_{1}=1-\left(\frac{\left|\mathrm{A}_{\mathrm{GCM}}-\mathrm{A}_{\text {WFDEI }}\right|}{2 \cdot \mathrm{A}_{\text {WFDEI }}}\right)^{0.5} \\
& \mathrm{f}_{2}=1-\left(\frac{\left|\mathrm{A}_{\mathrm{GCM}-}^{+} \mathrm{A}_{\mathrm{WFDEI}}^{+}\right|}{2 \cdot \mathrm{A}_{\mathrm{WFDEI}}^{+}}\right)^{0.5} \\
& \mathrm{f}_{3}=1-\left(\frac{\left|\mathrm{A}_{\mathrm{GCM}}^{-}-\mathrm{A}_{\mathrm{WFDEI}}^{-}\right|}{2 \cdot \mathrm{A}_{\mathrm{WFDEI}}^{-}}\right)^{0.5} \\
& \mathrm{f}_{4}=1-\left(\frac{\left|\overline{\mathrm{P}_{\mathrm{GCM}}}-\overline{\mathrm{P}_{\mathrm{WFDEI}}}\right|}{2 \cdot \overline{\mathrm{P}_{\mathrm{WFDEI}}}}\right)^{0.5} \\
& \mathrm{f}_{5}=1-\left(\frac{\left|\sigma_{\mathrm{GCM}}-\sigma_{\mathrm{WFDEI}}\right|}{2 \cdot \sigma_{\mathrm{WFDEI}}}\right)^{0.5}
\end{aligned}
$$

where $A_{G C M}$ and $A_{\text {WFDEI }}$ are the fractional areas over $(+)$ and under $(-)$ the 50 th percentile, respectively, and $\mathrm{A}^{+}$and $\mathrm{A}^{-}$are the fractional areas below the simulated (climate model) and observed precipitation cumulative density function (PDF) curves. The standard deviation of the probability distribution function is $\sigma, \mathrm{P}$ that denotes the average annual precipitation over the Upper Blue Nile Basin. Each of the aforementioned elements is meant to cover distinct parts of the probability distribution feature of climate models, such as the mean and total area (Equations (5) and (8)), smaller and greater amounts of precipitation (Equations (6) and (7)), and the form of the distribution (Equation (9)). Each model j: multiplies these five influencing factors to arrive at a single rainfall skill rating.

$$
\mathrm{sk}_{\text {prec }}=\mathrm{f}_{1} \cdot \mathrm{f}_{2} \cdot \mathrm{f}_{3} \cdot \mathrm{f}_{4} \cdot \mathrm{f}_{5}
$$

Finally, the overall skill or rank is multiplied by all of the skill ratings for reproducing reference temperature and precipitation, as well as the rankings/scores based on variations in the means and extremes:

$$
\text { Final skill score }=\mathrm{sk}_{\mathrm{EI}_{1}} \cdot \mathrm{sk}_{\mathrm{EI}_{2}} \cdot \mathrm{sk}_{\Delta \mathrm{P}} \cdot \mathrm{sk}_{\Delta \mathrm{T}} \cdot \mathrm{sk}_{\mathrm{Temp}} \cdot \mathrm{sk}_{\mathrm{prec}}
$$

A greater score implies better performance in this skill category, whereas a lower one suggests poor performance. For each group of climate models, these competence ratings can be converted into a simple ranking from 1 to 5 .

The climate model selection strategy used in this study follows the approach and methods proposed by $[6,14,40,43,44]$ with a few tweaks to the evaluation criteria. 


\section{Results}

\subsection{Selection of Models}

\subsubsection{Changes in Climatic Means}

For both RCP4.5 and RCP8.5, a total of 25 models were chosen from the 105 and 78 models encompassing all ensemble members, respectively, based on changes in mean air temperature and annual sum of precipitation between 2071-2100 and 1971-2000. Figure 2 and Table 2 show the results of the initial short-listing of the GCM model runs. Only those GCM runs were kept in this step that exhibited minimal differences with the 10th, 50th, and 90th percentile values of $\Delta \mathrm{T}\left({ }^{\circ} \mathrm{C}\right)$ and $\Delta \mathrm{P}(\%)$, which were resulting in sets of five GCM runs at each corner and five in the center for each RCP with the remaining model runs not being processed further. For each RCP, a total of 20 model runs were chosen in this manner. It is worth noting that the RCP8.5 model pool's range of forecasts for $\Delta \mathrm{T}$ and $\Delta \mathrm{P}$ was substantially greater than the $\mathrm{RCP} 4.5$ model pools. $\triangle \mathrm{P}$ varies from $-11.80 \%$ to $60.83 \%$ for the latter, more extreme $\mathrm{RCP}$, and $\mathrm{T}$ ranges from $2.41^{\circ} \mathrm{C}$ to $5.58{ }^{\circ} \mathrm{C}$; however, these ranges are substantially greater for the former (RCP4.5), with $\triangle \mathrm{P}$ ranging between $10.24 \%$ and $42.66 \%$ and $\Delta \mathrm{T}$ between $0.92{ }^{\circ} \mathrm{C}$ and $3.49^{\circ} \mathrm{C}$. The differences between the 10th, 50 th, and 90th percentile values in the relevant corner or center were also utilized to rank the GCM runs that were shortlisted. This rating was established to be utilized in the final selection process so that the model runs that best represent the group of models or kind of situation (Warm-Wet, Warm-Dry, Cold-Wet, Cold-Dry, or the Median) are prioritized. The terms "Wet-Cold" and "Dry-Cold" in the "Wet-Cold" and "Dry-Cold" scenarios do not indicate that future temperatures will be colder than the reference period, but instead that future warming will be lower than the Warm scenarios. In the scenarios "Dry-Cold" and "Dry-Warm", the labels Dry and Warm are just descriptive of the scenario's relative position to others.

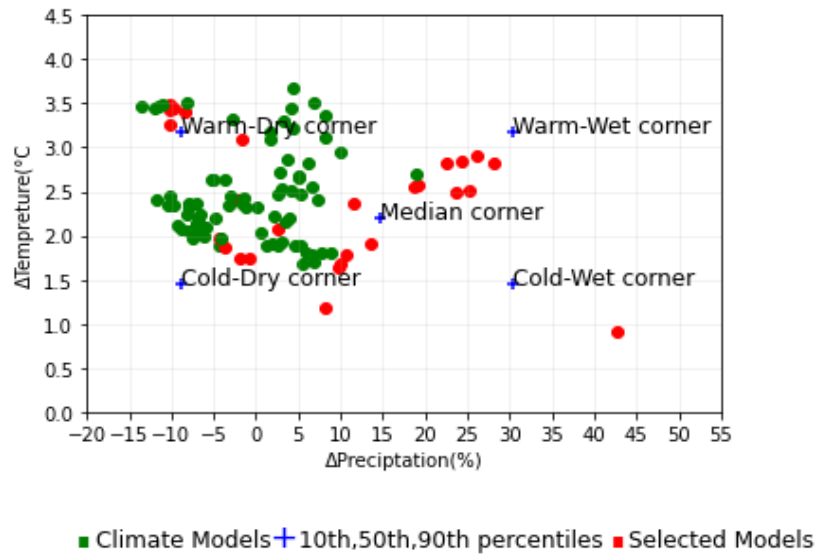

(a)

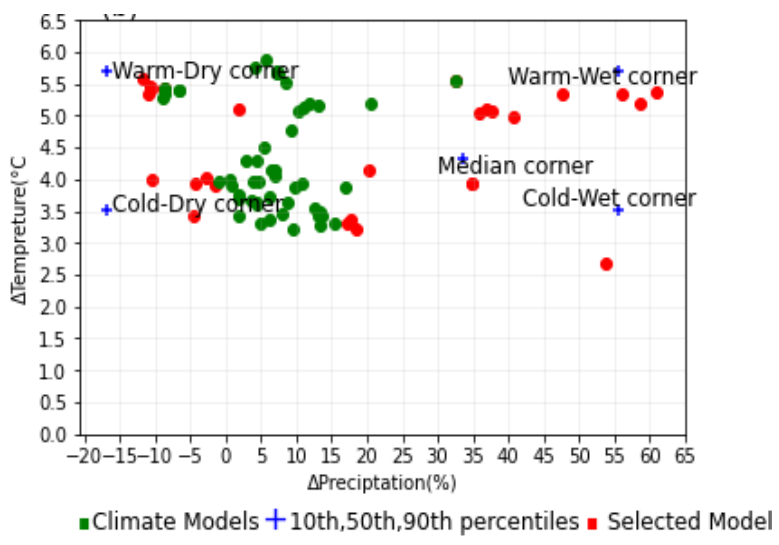

(b)

Figure 2. Changes in mean air temperature $(\Delta \mathrm{T})$ and annual precipitation sum $(\Delta \mathrm{P})$ projected for all included GCM runs (a) for RCP4.5 and (b) for RCP8.5 between 2071 and 2100 as well as 1971 and 2000. The full-spectrum corners for $\Delta \mathrm{T}$ and $\Delta \mathrm{P}$ are indicated by blue crosses. The model runs that were chosen are highlighted in red, while the model runs that were shortlisted are represented in green. 
Table 2. Initially selected models using Change in climatic means for RCP 4.5 and RCP8.5.

\begin{tabular}{|c|c|c|c|c|c|c|}
\hline Scenario & RCP4.5 & & & RCP8.5 & & \\
\hline RCP Projection & Model & $\Delta \mathrm{P}(\%)$ & $\Delta \mathrm{T}\left({ }^{\circ} \mathrm{C}\right)$ & Model & $\Delta \mathrm{P}(\%)$ & $\Delta \mathrm{T}\left({ }^{\circ} \mathrm{C}\right)$ \\
\hline \multirow{5}{*}{ Warm-Dry } & CSIRO-Mk3-6-0_r8i1p1 & -10.22 & 3.25 & CSIRO-Mk3-6-0_r4i1p1 & -11.7 & 5.58 \\
\hline & CSIRO-Mk3-6-0_r3i1p1 & -8.35 & 3.41 & CSIRO-Mk3-6-0_r1i1p1 & -10.7 & 5.47 \\
\hline & CSIRO-Mk3-6-0_r6i1p1 & -9.75 & 3.44 & CSIRO-Mk3-6-0_r8i1p1 & -11.8 & 5.25 \\
\hline & CSIRO-Mk3-6-0_r1i1p1 & -10.24 & 3.42 & CSIRO-Mk3-6-0_r2i1p1 & -10.5 & 5.43 \\
\hline & CSIRO-Mk3-6-0_r2i1p1 & -10.08 & 3.49 & CSIRO-Mk3-6-0_r7i1p1 & -11 & 5.33 \\
\hline \multirow{5}{*}{ Cold-Dry } & GFDL-ESM2G_r1i1p1 & -0.71 & 1.75 & GISS-E2-H_r1i1p1 & -10.5 & 3.98 \\
\hline & FIO-ESM_r3i1p1 & -4.37 & 1.9 & GISS-E2-R_r1i1p1 & -4.5 & 3.44 \\
\hline & GISS-E2-R_r5i1p1 & -3.59 & 1.87 & GISS-E2-H_r1i1p2 & -4.23 & 3.93 \\
\hline & FIO-ESM_r2i1p1 & -4.3 & 1.97 & GFDL-ESM2G_r1i1p1 & -1.4 & 3.91 \\
\hline & inmcm4_r1i1p1 & -2.00 & 1.75 & FIO-ESM_r2i1p1 & -2.71 & 4.01 \\
\hline \multirow{5}{*}{ Cold-Wet } & CanESM2_r5i1p1 & 23.68 & 2.48 & BNU-ESM_r1i1p1 & 53.69 & 2.69 \\
\hline & BNU-ESM_r1i1p1 & 42.66 & 0.92 & FGOALS_g2_r1i1p1 & 20.19 & 2.41 \\
\hline & FGOALS_g2_r1i1p1 & 8.24 & 1.19 & CESM1-BGC_r1i1p1 & 18.48 & 3.21 \\
\hline & CCSM4_r4i1p1 & 9.99 & 1.69 & CCSM4_r6i1p1 & 17.73 & 3.36 \\
\hline & CCSM4_r2i1p1 & 9.68 & 1.65 & CCSM4_r2i1p1 & 17.15 & 3.32 \\
\hline \multirow{6}{*}{ Warm-Wet } & IPSL-CM5A-LR_r3i1p1 & 26.17 & 2.91 & IPSL-CM5A-LR_r2i1p1 & 56.03 & 5.35 \\
\hline & IPSL-CM5A-LR_r1i1p1 & 28.12 & 2.82 & IPSL-CM5A-LR_r1i1p1 & 60.83 & 5.38 \\
\hline & IPSL-CM5A-LR_r4i1p1 & 24.42 & 2.85 & IPSL-CM5A-LR_r3i1p1 & 47.55 & 5.35 \\
\hline & IPSL-CM5A-LR_r2i1p1 & 22.42 & 2.82 & IPSL-CM5A-LR_r4i1p1 & 58.57 & 5.2 \\
\hline & CanESM2_r4i1p1 & 25.12 & 2.52 & CanESM2_r5i1p1 & 45.94 & 4.92 \\
\hline & IPSL-CM5A-LR_r3i1p1 & 26.17 & 2.91 & IPSL-CM5A-LR_r2i1p1 & 56.03 & 5.35 \\
\hline \multirow{5}{*}{$\begin{array}{l}\text { Mean (50th } \\
\text { percentile) }\end{array}$} & CESM1-CAM5_r2i1p1 & 11.54 & 2.36 & CanESM2_r1i1p1 & 37.67 & 5.06 \\
\hline & bcc-csm1-1-m_r1i1p1 & 10.73 & 1.78 & CanESM2_r2i1p1 & 36.95 & 5.09 \\
\hline & CanESM2_r3i1p1 & 19.16 & 2.58 & CanESM2_r3i1p1 & 35.94 & 5.04 \\
\hline & CanESM2_r1i1p1 & 18.72 & 2.56 & CanESM2_r4i1p1 & 40.82 & 4.97 \\
\hline & IPSL-CM5B-LR_r1i1p1 & 13.59 & 1.92 & IPSL-CM5B-LR_r1i1p1 & 34.77 & 3.94 \\
\hline
\end{tabular}

\subsubsection{Changes in Climatic Extremes}

Based on expected changes in climatic extremes, the 20 model runs chosen for each RCP were explored further. Table 3 details the expected improvements in a number of critical indices. The model runs with the highest changes in the extreme indices for each of the corners are as follows: Warm-Wet, Warm-Dry, Cold-Wet, and Cold-Dry receive priority during the final pick comparable to the rank assigned based on changes in the means. The center or mean situations, unlike the four corners, were not examined using extreme indices. Tables 3 and 4 show the ranking and scores for the means and severe indices as well as the ability scores for reproducing reference climate for RCP4.5 and RCP8.5, respectively. The model run with the largest or lowest changes in mean precipitation or temperature also has the highest or lowest change in the related extreme index most of the time. For "Wet" scenarios, the R99pTOT (\%) index was utilized, while for "Dry" scenarios, the CDD $(\%)$ index was employed. WSDI (\%) was utilized for the "Warm" scenarios, while CSDI $(\%)$ was used for the "Cold" scenarios. In this approach, a collection of two (2) indices were examined for each of the four (4) scenarios: Warm-Wet, Warm-Dry, Cold-Wet, and Cold-Dry. 
Table 3. Selection of remaining models using the change in climatic extremes for RCP 4.5.

\begin{tabular}{|c|c|c|c|c|c|}
\hline RCP Projection & Model & $\Delta$ R99P Tot $(\%)$ & $\Delta \mathrm{CDD}(\%)$ & $\Delta$ WSDI (\%) & $\Delta$ CSDI $(\%)$ \\
\hline \multirow{5}{*}{ Warm-Dry } & CSIRO-Mk3-6-0_r8i1p1 & 26.35 & -10.02 & 1959.46 & -98.07 \\
\hline & CSIRO-Mk3-6-0_r3i1p1 & 12.57 & -8.31 & 2677.96 & -97.48 \\
\hline & CSIRO-Mk3-6-0_r6i1p1 & 17.59 & -9.34 & 1871.25 & -98.22 \\
\hline & CSIRO-Mk3-6-0_r1i1p1 & 24.91 & -9.77 & 2501.96 & -98.78 \\
\hline & CSIRO-Mk3-6-0_r2i1p1 & 25.92 & -9.74 & 2451.11 & -98.05 \\
\hline \multirow{5}{*}{ Cold-Dry } & GFDL-ESM2G_r1i1p1 & 32.9 & -2.1 & 634.53 & -93.63 \\
\hline & FIO-ESM_r3i1p1 & - & - & - & - \\
\hline & GISS-E2-R_r5i1p1 & - & - & - & - \\
\hline & FIO-ESM_r2i1p1 & - & - & - & - \\
\hline & inmcm4_r1i1p1 & $5 . \overline{41}$ & $-\overline{3.34}$ & $85 \overline{8.61}$ & $-\overline{52.22}$ \\
\hline \multirow{5}{*}{ Wet-Cold } & BNU-ESM_r1i1p1 & - & - & - & - \\
\hline & bcc-csm1-1-m_r1i1p1 & $7 \overline{1.71}$ & $\overline{5.36}$ & $9 \overline{44} .7$ & $-\overline{87.52}$ \\
\hline & FGOALS_g2_r1i1p1 & - & - & - & - \\
\hline & CCSM4_r4i1p1 & - & - & - & - \\
\hline & CCSM4_r2i1p1 & 80.39 & 3.46 & $87 \overline{9} .57$ & -83.52 \\
\hline \multirow{5}{*}{ Wet-Warm } & IPSL-CM5A-LR_r3i1p1 & 182.56 & 12.66 & 1575.59 & -96.59 \\
\hline & IPSL-CM5A-LR_r1i1p1 & 210.48 & 13.43 & 1081.35 & -94.09 \\
\hline & IPSL-CM5A-LR_r4i1p1 & 136.30 & 11.511 & 1476.11 & -96.55 \\
\hline & IPSL-CM5A-LR_r2i1p1 & 200.19 & 8.766 & 914.82 & -95.67 \\
\hline & CanESM2_r4i1p1 & 80.96 & 5.24 & 859.92 & -90.38 \\
\hline
\end{tabular}

_ Sign indicates that there are no extreme indices data for those listed models in Table 4.

Table 4. Selection of remaining models using the change in climatic extremes for RCP8.5.

\begin{tabular}{|c|c|c|c|c|c|}
\hline RCP Projection & Model & $\Delta \mathrm{R} 99 \mathrm{P}$ Tot $(\%)$ & $\Delta \mathrm{CDD}(\%)$ & $\Delta$ WSDI (\%) & $\Delta$ CSDI (\%) \\
\hline \multirow{5}{*}{ Warm-Dry } & GISS-E2-H_r1i1p1 & $\ldots$ & $\ldots$ & $\ldots$ & - \\
\hline & GISS-E2-R_r1i1p1 & $\overline{-}$ & $\overline{-}$ & $\overline{-}$ & 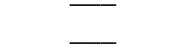 \\
\hline & GISS-E2-H_r1i1p2 & & & & \\
\hline & GFDL-ESM2G_r1i1p1 & $1 \overline{24.26}$ & $\overline{-5.99}$ & $137 \overline{76.13}$ & $-\overline{99.79}$ \\
\hline & FIO-ESM_r2i1p1 & - & - & - & - \\
\hline \multirow{5}{*}{ Cold-Dry } & CSIRO-Mk3-6-0_r4i1p1 & 37.83 & -13.58 & 3525.97 & -99.98 \\
\hline & CSIRO-Mk3-6-0_r1i1p1 & 68.59 & -13.19 & 3227.31 & -99.68 \\
\hline & CSIRO-Mk3-6-0_r8i1p1 & 15.44 & 4.99 & 2546.26 & -100 \\
\hline & CSIRO-Mk3-6-0_r2i1p1 & 3.05 & -11.49 & 3102.2 & -99.78 \\
\hline & CSIRO-Mk3-6-0_r7i1p1 & 19.83 & -12.21 & 4388.02 & -99.85 \\
\hline \multirow{5}{*}{ Wet-Cold } & BNU-ESM_r1i1p1 & 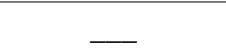 & - & 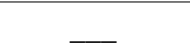 & 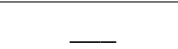 \\
\hline & FGOALS_g2_r1i1p1 & $\overline{-}$ & - & - & $\overline{-}$ \\
\hline & CESM1-BGC_r1i1p1 & 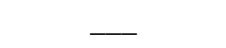 & - & - & - \\
\hline & CCSM4_r6i1p1 & 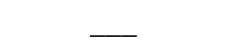 & 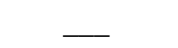 & - & - \\
\hline & CCSM4_r2i1p1 & 158.93 & 5.49 & 1835.49 & -97.79 \\
\hline \multirow{5}{*}{ Wet-Warm } & IPSL-CM5A-LR_r2i1p1 & 709.7 & 21.26 & 1094.01 & -94.79 \\
\hline & IPSL-CM5A-LR_r1i1p1 & 638 & 24.34 & 1305.77 & -92.69 \\
\hline & IPSL-CM5A-LR_r3i1p1 & 420.94 & 19.96 & 1988.23 & -90.75 \\
\hline & IPSL-CM5A-LR_r4i1p1 & 604.9 & 21.26 & 1791.89 & -95.09 \\
\hline & CanESM2_r4i1p1 & 80.96 & 5.24 & 859.92 & -90.38 \\
\hline
\end{tabular}


Table 5. Selection of models using past performance for RCP4.5 and RCP8.5.

\begin{tabular}{|c|c|c|c|c|c|c|}
\hline Scenario & $\mathrm{RCP} 4.5$ & & & & RCP8.5 & \\
\hline RCP Projection & Model & Tscore & P Score & Model & Tscore & P Score \\
\hline \multirow{5}{*}{ Warm-Dry } & CSIRO-Mk3-6-0_r8i1p1 & 0.63 & 0.23 & CSIRO-Mk3-6-0_r4i1p1 & 0.55 & 0.36 \\
\hline & CSIRO-Mk3-6-0_r3i1p1 & 0.62 & 0.26 & CSIRO-Mk3-6-0_r1i1p1 & 0.52 & 0.39 \\
\hline & CSIRO-Mk3-6-0_r6i1p1 & 0.55 & 0.25 & CSIRO-Mk3-6-0_r8i1p1 & 0.55 & 0.41 \\
\hline & CSIRO-Mk3-6-0_r1i1p1 & 0.59 & 0.38 & CSIRO-Mk3-6-0_r2i1p1 & 0.55 & 0.16 \\
\hline & CSIRO-Mk3-6-0_r2i1p1 & 0.65 & 0.24 & CSIRO-Mk3-6-0_r7i1p1 & 0.51 & 0.34 \\
\hline \multirow{5}{*}{ Cold-Dry } & GFDL-ESM2G_r1i1p1 & 0.55 & 0.41 & GISS-E2-H_r1i1p1 & 0.66 & 0.25 \\
\hline & FIO-ESM_r3i1p1 & 0.53 & 0.43 & GISS-E2-R_r1i1p1 & 0.63 & 0.22 \\
\hline & GISS-E2-R_r5i1p1 & 0.54 & 0.52 & GISS-E2-H_r1i1p2 & 0.68 & 0.03 \\
\hline & FIO-ESM_r2i1p1 & 0.49 & 0.46 & GFDL-ESM2G_r1i1p1 & 0.66 & 0.22 \\
\hline & inmcm4_r1i1p1 & 0.52 & 0.44 & FIO-ESM_r2i1p1 & 0.58 & 0.43 \\
\hline \multirow{5}{*}{ Cold-Warm } & CanESM2_r5i1p1 & 0.58 & 0.40 & BNU-ESM_r1i1p1 & 0.64 & 0.36 \\
\hline & BNU-ESM_r1i1p1 & 0.64 & 0.35 & FGOALS_g2_r1i1p1 & 0.59 & 0.46 \\
\hline & FGOALS_g2_r1i1p1 & 0.59 & 0.37 & CESM1-BGC_r1i1p1 & 0.6 & 0.21 \\
\hline & CCSM4_r4i1p1 & 0.56 & 0.51 & CCSM4_r6i1p1 & 0.58 & 0.27 \\
\hline & CCSM4_r2i1p1 & 0.60 & 0.51 & CCSM4_r2i1p1 & 0.60 & 0.45 \\
\hline \multirow{5}{*}{ Warm-Wet } & IPSL-CM5A-LR_r3i1p1 & 0.60 & 0.35 & IPSL-CM5A-LR_r2i1p1 & 0.57 & 0.43 \\
\hline & IPSL-CM5A-LR_r1i1p1 & 0.64 & 0.35 & IPSL-CM5A-LR_r1i1p1 & 0.64 & 0.38 \\
\hline & IPSL-CM5A-LR_r4i1p1 & 0.60 & 0.39 & IPSL-CM5A-LR_r3i1p1 & 0.46 & 0.14 \\
\hline & IPSL-CM5A-LR_r2i1p1 & 0.57 & 0.39 & IPSL-CM5A-LR_r4i1p1 & 0.60 & 0.14 \\
\hline & CanESM2_r4i1p1 & 0.57 & 0.32 & CanESM2_r5i1p1 & 0.58 & 0.40 \\
\hline \multirow{5}{*}{ Mean } & CESM1-CAM5_r2i1p1 & 0.59 & 0.62 & CanESM2_r1i1p1 & 0.57 & 0.25 \\
\hline & bcc-csm1-1-m_r1i1p1 & 0.62 & 0.44 & CanESM2_r2i1p1 & 0.49 & 0.44 \\
\hline & CanESM2_r3i1p1 & 0.56 & 0.32 & CanESM2_r3i1p1 & 0.56 & 0.39 \\
\hline & CanESM2_r1i1p1 & 0.57 & 0.25 & CanESM2_r4i1p1 & 0.57 & 0.43 \\
\hline & IPSL-CM5B-LR_r1i1p1 & 0.58 & 0.30 & IPSL-CM5B-LR_r1i1p1 & 0.58 & 0.27 \\
\hline
\end{tabular}

\subsubsection{Past Performance}

The final model is chosen based on model performance validation against the WFDEI dataset. The model runs were evaluated for their ability to recreate the reference precipitation and temperature data after an evaluation of their anticipated changes in averages and extreme indices. Table 5 shows the expected skill ratings for the remaining GCM runs resulting from climate extremes. The last skill scores and ranks were generated by multiplying all relevant skill scores awarded to each model run by a factor of two after awarding skill scores based on historical performance. Each scenario was assigned a final rank, with the model run with the highest final skill score receiving the highest rank, and so forth. The temperature skills score of all selected models is higher than the precipitation score in both RCP4.5 and RCP8.5. The wet warm corner received the lowest precipitation skill score for RCP8.5. Despite the fact that the proposed method aims to combine the benefits of envelope-based and past-performance-based GCM selection for impact assessments, it has scale constraints in both climatic mean and extreme mean analyses when averaging the entire area $[6,14]$. The skill scores of both precipitation and temperature were calculated for the entire area after subdividing into 16 sub-basins (Tables 6 and 7). Except for a few sub-basins, all models have shown higher precipitation and temperature skill scores compared to without subdividing the entire study area. 
Table 6. Skill scores for GCM runs remaining after Step 2.

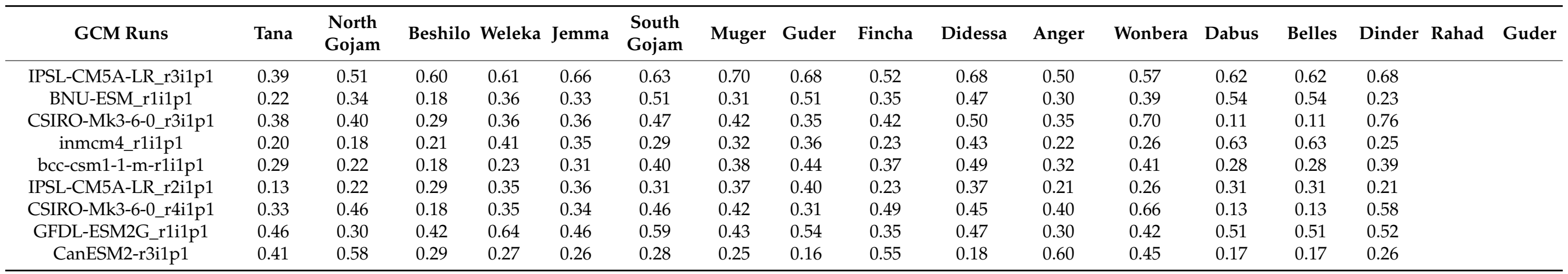

Table 7. Skill scores for GCM runs of mean air temperature remaining after Step 2.

\begin{tabular}{|c|c|c|c|c|c|c|c|c|c|c|c|c|c|c|c|c|c|}
\hline GCM Runs & Tana & $\begin{array}{l}\text { North } \\
\text { Gojam }\end{array}$ & Beshilo & Weleka & Jemma & $\begin{array}{l}\text { South } \\
\text { Gojam }\end{array}$ & Muger & Guder & Fincha & Didessa & Anger & Wonbera & Dabus & Belles & Dinder & Rahad & Guder \\
\hline IPSL-CM5A-LR_r3i1p1 & 0.46 & 0.57 & 0.63 & 0.63 & 0.58 & 0.58 & 0.56 & 0.69 & 0.60 & 0.66 & 0.61 & 0.65 & 0.67 & 0.60 & 0.59 & & \\
\hline BNU-ESM_r1i1p1 & 0.35 & 0.43 & 0.60 & 0.56 & 0.55 & 0.63 & 0.56 & 0.66 & 0.66 & 0.65 & 0.65 & 0.63 & 0.72 & 0.66 & 0.69 & & \\
\hline inmcm4_r1i1p1 & 0.56 & 0.51 & 0.56 & 0.47 & 0.47 & 0.44 & 0.47 & 0.46 & 0.45 & 0.45 & 0.47 & 0.47 & 0.53 & 0.54 & 0.56 & & \\
\hline bcc-csm1-1-m-r1i1p1 & 0.56 & 0.70 & 0.60 & 0.61 & 0.61 & 0.62 & 0.69 & 0.68 & 0.66 & 0.71 & 0.68 & 0.66 & 0.63 & 0.61 & 0.57 & & \\
\hline IPSL-CM5A-LR_r2i1p1 & 0.46 & 0.53 & 0.58 & 0.59 & 0.60 & 0.56 & 0.55 & 0.66 & 0.57 & 0.68 & 0.61 & 0.61 & 0.66 & 0.58 & 0.61 & & \\
\hline CSIRO-Mk3-6-0_r4i1p1 & 0.45 & 0.48 & 0.52 & 0.54 & 0.57 & 0.51 & 0.49 & 0.72 & 0.49 & 0.69 & 0.52 & 0.69 & 0.68 & 0.65 & 0.68 & & \\
\hline CanESM2-r3i1p1 & 0.53 & 0.62 & 0.51 & 0.54 & 0.52 & 0.61 & 0.50 & 0.63 & 0.64 & 0.62 & 0.61 & 0.60 & 0.60 & 0.64 & 0.64 & & \\
\hline
\end{tabular}




\subsubsection{The Weighted Rank of the Overall Steps}

The result of the overall weighted rank of all steps used in this study is shown in Tables 8 and 9 for RCP4.5 and RCP8.5, respectively. Even though all the five selected model in the dry cold corner in both RCP4.5 and RCP8.5 shows the best performance, they are not be preferred for climate change impact study due to lack of daily precipitation and temperature data. So, in the spectrum of the dry corner in both RCP4.5 and RCP8.5, FIO-ESM-r3i1p1 and FIO-ESM_r2i1p1 were replaced by Inmcm4_r1i1p1 and GFDL-ESM2G_r1i1p1, respectively.

Table 8. For all eligible RCP4.5 GCM runs, change in means (e and f), change in extremes (a, b, c, and $\mathrm{d})$, and skill ratings for recreating reference precipitation and air temperature ( $\mathrm{g}$ and $\mathrm{h}$ ).

\begin{tabular}{|c|c|c|c|c|c|c|c|c|c|c|c|}
\hline & & $\mathbf{a}$ & b & c & d & e & f & g & h & & \\
\hline Projection & Climate Model & $\begin{array}{c}\text { Weighted } \\
\text { Rank } \\
\Delta \text { R99pTOT } \\
(\%)\end{array}$ & $\begin{array}{c}\text { Weighted } \\
\text { Rank } \\
\Delta \text { CDD } \\
(\%)\end{array}$ & $\begin{array}{c}\text { Weighted } \\
\text { Rank } \\
\Delta \text { WSDI } \\
(\%)\end{array}$ & $\begin{array}{c}\text { Weighted } \\
\text { Rank } \\
\Delta \text { CSDI } \\
(\%)\end{array}$ & $\begin{array}{l}\text { Weighted } \\
\text { Rank } \Delta \mathrm{T} \\
\left({ }^{\circ} \mathrm{C}\right)\end{array}$ & $\begin{array}{l}\text { Weighted } \\
\text { Rank } \Delta P \\
(\%)\end{array}$ & $\begin{array}{c}\text { Skill } \\
\text { Score } \\
\text { for Tem- } \\
\text { perature } \\
\text { (SkTmp) }\end{array}$ & $\begin{array}{l}\text { Skill } \\
\text { Score } \\
\text { for } \\
\text { Precipi- } \\
\text { tation } \\
\text { (SkPerc) }\end{array}$ & $\begin{array}{c}\text { Final } \\
\text { Skill } \\
\text { Score }(\mathbf{a} * \\
\mathbf{b} * \mathbf{c} * \mathbf{d} * \\
\mathbf{e} * \mathbf{f} * \mathbf{g} * \\
\mathbf{h} * \mathbf{1 0})\end{array}$ & $\begin{array}{l}\text { Final } \\
\text { Rank }\end{array}$ \\
\hline \multirow{5}{*}{ Wet-Warm } & $\begin{array}{l}\text { IPSL-CM5A- } \\
\text { LR_r3i1p1 }\end{array}$ & 0.87 & - & 1 & - & 0.92 & 0.87 & 0.6 & 0.35 & 1.46 & 1 \\
\hline & $\begin{array}{l}\text { IPSL-CM5A- } \\
\text { LR_r1i1p1 }\end{array}$ & 1 & - & 0.69 & - & 0.89 & 0.93 & 0.64 & 0.35 & 1.27 & 2 \\
\hline & $\begin{array}{l}\text { IPSL-CM5A- } \\
\text { LR_r4i1p1 }\end{array}$ & 0.65 & - & 0.94 & - & 0.9 & 0.81 & 0.6 & 0.39 & 1.02 & 3 \\
\hline & $\begin{array}{l}\text { IPSL-CM5A- } \\
\text { LR_r2i1p1 }\end{array}$ & 0.95 & - & 0.58 & - & 0.89 & 0.74 & 0.57 & 0.39 & 0.82 & 4 \\
\hline & CanESM2_r4i1p1 & 0.77 & - & 0.55 & - & 0.79 & 0.83 & 0.57 & 0.32 & 0.5 & 5 \\
\hline \multirow{5}{*}{ Wet-Cold } & CanESM2_r5i1p1 & 0.7 & - & - & 0.96 & 0.3 & 0.78 & 0.58 & 0.4 & 0.36 & 4 \\
\hline & BNU-ESM_r1i1p1 & - & - & - & - & 0.63 & 0.59 & 0.64 & 0.35 & 0.84 & 1 \\
\hline & $\begin{array}{l}\text { FGOALS_g2 } \\
\text { r1i1p1 }\end{array}$ & - & - & - & - & 0.82 & 0.27 & 0.59 & 0.37 & 0.48 & 3 \\
\hline & CCSM4_r4i1p1 & - & - & - & - & 0.84 & 0.33 & 0.56 & 0.51 & 0.8 & 2 \\
\hline & CCSM4_r2i1p1 & 1 & 0.35 & 0.33 & 0.85 & 0.87 & 0.32 & 0.6 & 0.51 & 0.08 & 5 \\
\hline \multirow{5}{*}{ Dry-Warm } & $\begin{array}{l}\text { CSIRO-Mk3-6- } \\
\text { 0_r8i1p1 }\end{array}$ & - & 1 & 0.73 & - & 0.97 & 0.86 & 0.55 & 0.41 & 1.4 & 5 \\
\hline & $\begin{array}{l}\text { CSIRO-Mk3-6- } \\
\text { 0_r3i1p1 }\end{array}$ & - & 0.83 & 1 & - & 0.92 & 0.93 & 0.53 & 0.43 & 1.614 & 1 \\
\hline & $\begin{array}{l}\text { CSIRO-Mk3-6- } \\
\text { 0_r6i1p1 }\end{array}$ & - & 0.93 & 0.7 & - & 0.91 & 0.91 & 0.54 & 0.52 & 1.53 & 4 \\
\hline & $\begin{array}{l}\text { CSIRO-Mk3-6- } \\
\text { 0_r1i1p1 }\end{array}$ & - & 0.98 & 0.93 & - & 0.92 & 0.86 & 0.49 & 0.46 & 1.613 & 2 \\
\hline & $\begin{array}{l}\text { CSIRO-Mk3-6- } \\
\text { 0_r2i1p1 }\end{array}$ & - & 0.97 & 0.92 & - & 0.9 & 0.87 & 0.52 & 0.44 & 1.59 & 3 \\
\hline \multirow{5}{*}{ Dry-Cold } & GISS-E2-R_r1i1p1 & - & 0.06 & - & 0.95 & 0.64 & 0.83 & 0.63 & 0.23 & 0.04 & 5 \\
\hline & GISS-E2-R_r4i1p1 & - & - & - & - & 0.61 & 0.74 & 0.62 & 0.26 & 0.71 & 2 \\
\hline & GISS-E2-R_r3i1p1 & - & - & - & - & 0.63 & 0.7 & 0.55 & 0.25 & 0.61 & 3 \\
\hline & FIO-ESM_r3i1p1 & - & - & - & - & 0.7 & 0.49 & 0.59 & 0.38 & 0.77 & 1 \\
\hline & inmcm4_r1i1p1 & - & 1 & - & 0.558 & 0.71 & 0.4 & 0.65 & 0.24 & 0.25 & 4 \\
\hline \multirow{5}{*}{ Mean } & $\begin{array}{c}\text { CESM1- } \\
\text { CAM5_r2i1p1 }\end{array}$ & - & - & - & - & 0.93 & 0.79 & 0.59 & 0.62 & 2.69 & 1 \\
\hline & $\begin{array}{l}\text { bcc-csm1-1- } \\
\text { m_r1i1p1 }\end{array}$ & - & - & - & - & 0.81 & 0.73 & 0.62 & 0.44 & 1.62 & 2 \\
\hline & CanESM2_r3i1p1 & - & - & - & - & 0.83 & 0.69 & 0.56 & 0.32 & 1.02 & 4 \\
\hline & CanESM2_r1i1p1 & - & - & - & - & 0.84 & 0.72 & 0.57 & 0.25 & 0.87 & 5 \\
\hline & $\begin{array}{l}\text { IPSL-CM5B- } \\
\text { LR_r1i1p1 }\end{array}$ & - & - & - & - & 0.87 & 0.93 & 0.58 & 0.3 & 1.41 & 3 \\
\hline
\end{tabular}

Note: — indicated that extreme value is not considered due to the four corners that means the variation of dry and warm projection.

\subsection{Future Climate in the Upper Blue Nile Basin}

Mean air temperature rises by $0.92-3.41{ }^{\circ} \mathrm{C}$ for RCP4.5 and $2.69-5.58^{\circ} \mathrm{C}$ for RCP8.5 between 1971-2000 and 2071-2100, according to selected ensembles of GCM runs. The selected ensembles of GCM runs mean extreme indices Precipitation wet days (R99PToT) is between 5.41-709.7\%, Consecutive dry days (CDD) -13.58-21.26\%, Warm spell duration index (WSDI) 858.61-3525.97\% and Cold spell duration index (CSDI) -99.98--52.22\%. Table 10 shows predicted increases in mean air temperature, precipitation, and ETCDDI indices for selected ensembles of GCM runs 1971-2000 and 2071-2100 over the Upper Blue Nile Basin. The projected changes in mean air temperature $(\Delta T)$, warm period duration 
index (WSDI), cold period duration index (CSDI) between 2071-2100 and 1971-2000 for RCP4.5 are in Figure 3a and RCP8.5 shown in Figure 3c. Between 2071-2100 and 1971-2000, projected increases in annual precipitation sum $(\mathrm{P})$, precipitation due to exceptionally wet days (R99pTOT), and consecutive dry days (CDD) for RCP4.5 are shown in Figure 3b and for RCP8.5 are shown in Figure 3d.

Table 9. For all RCP8.5 GCMs chosen, changes in means (e and f), extremes (a, b, c, and d), and skill ratings for simulating reference precipitation and air temperature ( $\mathrm{g}$ and $\mathrm{h}$ ).

\begin{tabular}{|c|c|c|c|c|c|c|c|c|c|c|c|}
\hline & & $\mathbf{a}$ & b & c & d & e & f & g & h & & \\
\hline Projection & Climate Model & $\begin{array}{c}\text { Weighted } \\
\text { Rank } \\
\Delta \text { R99pTOT } \\
(\%)\end{array}$ & $\begin{array}{c}\text { Weighted } \\
\text { Rank } \\
\Delta \text { CDD } \\
(\%)\end{array}$ & $\begin{array}{c}\text { Weighted } \\
\text { Rank } \\
\Delta \text { WSDI } \\
(\%)\end{array}$ & $\begin{array}{c}\text { Weighted } \\
\text { Rank } \\
\Delta \text { CSDI } \\
(\%)\end{array}$ & $\begin{array}{c}\text { Weighted } \\
\text { Rank } \Delta \mathrm{T} \\
\left({ }^{\circ} \mathrm{C}\right)\end{array}$ & $\begin{array}{c}\text { Weighted } \\
\text { Rank } \Delta P \\
(\%)\end{array}$ & $\begin{array}{l}\text { Skill } \\
\text { Score } \\
\text { for Tem- } \\
\text { perature } \\
\text { (SkTmp) }\end{array}$ & $\begin{array}{c}\text { Skill } \\
\text { Score } \\
\text { for } \\
\text { Precipi- } \\
\text { tation } \\
\text { (SkPerc) }\end{array}$ & $\begin{array}{c}\text { Final } \\
\text { Skill } \\
\text { Score }(\mathbf{a} * \\
\mathbf{b} * \mathbf{c} * \mathbf{d} * \\
\mathbf{e} * \mathbf{f} * \mathbf{g} * \\
\mathbf{h} * \mathbf{1 0})\end{array}$ & $\begin{array}{l}\text { Final } \\
\text { Rank }\end{array}$ \\
\hline \multirow{5}{*}{ Warm-Dry } & $\begin{array}{l}\text { CSIRO-Mk3-6- } \\
\text { 0_r4i1p1 }\end{array}$ & - & 1 & 0.8 & - & 0.98 & 0.7 & 0.55 & 0.36 & 1.08 & 1 \\
\hline & $\begin{array}{l}\text { CSIRO-Mk3-6- } \\
\text { 0_r1i1p1 }\end{array}$ & - & 0.97 & 0.74 & - & 0.96 & 0.64 & 0.52 & 0.39 & 0.89 & 3 \\
\hline & $\begin{array}{l}\text { CSIRO-Mk3-6- } \\
\text { 0_r8i1p1 }\end{array}$ & - & 0.37 & 0.58 & - & 0.92 & 0.7 & 0.55 & 0.41 & 0.31 & 4 \\
\hline & $\begin{array}{l}\text { CSIRO-Mk3-6- } \\
\text { 0 r2i1p1 }\end{array}$ & - & 0.85 & 0.71 & - & 0.95 & 0.63 & 0.55 & 0.16 & 0.3 & 5 \\
\hline & $\begin{array}{l}\text { CSIRTO-Mk3-6- } \\
\text { 0_r7i1p1 }\end{array}$ & - & 0.9 & 1 & - & 0.94 & 0.66 & 0.51 & 0.34 & 0.96 & 2 \\
\hline \multirow{5}{*}{ Cold-Dry } & GISS-E2-H_r1i1p1 & - & - & - & - & 0.87 & 0.37 & 0.66 & 0.25 & 0.52 & 4 \\
\hline & GISS-E2-R_r1i1p1 & - & - & - & - & 0.98 & 0.73 & 0.63 & 0.22 & 1.01 & 3 \\
\hline & GISS-E2-H_r1i1p2 & - & - & - & - & 0.88 & 0.75 & 0.68 & 0.03 & 0.15 & 5 \\
\hline & $\begin{array}{l}\text { GFDL- } \\
\text { ESM2G r1i1p1 }\end{array}$ & 1 & 1 & - & 1 & 0.88 & 0.92 & 0.66 & 0.22 & 1.17 & 2 \\
\hline & FIO-ESM_r2i1p1 & - & - & - & - & 0.86 & 0.84 & 0.58 & 0.43 & 1.79 & 1 \\
\hline \multirow{5}{*}{ Cold-Warm } & BNU-ESM_r1i1p1 & - & - & - & - & 0.77 & 0.97 & 0.64 & 0.36 & 1.69 & 1 \\
\hline & FGOALS_g2_r1i1p1 & - & - & - & - & 0.69 & 0.36 & 0.59 & 0.46 & 0.67 & 3 \\
\hline & $\begin{array}{c}\text { CESM1- } \\
\text { BGC r1i1p1 }\end{array}$ & - & - & - & - & 0.91 & 0.33 & 0.6 & 0.21 & 0.38 & 5 \\
\hline & CCSM4_r6i1p1 & - & - & - & - & 0.96 & 0.32 & 0.58 & 0.27 & 0.48 & 4 \\
\hline & CCSM4_r2i1p1 & 1 & - & - & 0.98 & 0.95 & 0.31 & 0.6 & 0.45 & 0.77 & 2 \\
\hline \multirow{5}{*}{ Warm-Wet } & $\begin{array}{l}\text { IPSL-CM5A- } \\
\text { LR_r2i1p1 }\end{array}$ & 1 & - & 0.55 & - & 0.94 & 0.99 & 0.57 & 0.43 & 1.27 & 1 \\
\hline & $\begin{array}{l}\text { IPSL-CM5A- } \\
\text { LR_r1i1p1 }\end{array}$ & 0.9 & - & 0.66 & - & 0.94 & 0.91 & 0.64 & 0.38 & 1.22 & 2 \\
\hline & $\begin{array}{l}\text { IPSL-CM5A- } \\
\text { LR_r3i1p1 }\end{array}$ & 0.59 & - & 1 & - & 0.94 & 0.86 & 0.46 & 0.14 & 0.31 & 5 \\
\hline & $\begin{array}{l}\text { IPSL-CM5A- } \\
\text { LR_r4i1p1 }\end{array}$ & 0.85 & - & 0.9 & - & 0.91 & 0.95 & 0.6 & 0.14 & 0.567 & 4 \\
\hline & CanESM2_r5i1p1 & 1 & - & 0.55 & - & 0.94 & 0.99 & 0.57 & 0.43 & 1.27 & 1 \\
\hline \multirow{5}{*}{ Mean } & CanESM2_r1i1p1 & - & - & - & - & 0.83 & 0.88 & 0.573 & 0.25 & 1.05 & 5 \\
\hline & CanESM2_r2i1p1 & - & - & - & - & 0.82 & 0.9 & 0.49 & 0.44 & 1.61 & 3 \\
\hline & CanESM2_r3i1p1 & - & - & - & - & 0.83 & 0.93 & 0.563 & 0.39 & 1.72 & 1 \\
\hline & CanESM2_r4i1p1 & - & - & - & - & 0.85 & 0.79 & 0.567 & 0.43 & 1.63 & 2 \\
\hline & $\begin{array}{l}\text { IPSL-CM5B- } \\
\text { LR_r1i1p1 }\end{array}$ & - & - & - & - & 0.91 & 0.97 & 0.577 & 0.27 & 1.37 & 4 \\
\hline
\end{tabular}

— indicated that extreme value is not considered due to the four corners that means the variation of dry and warm projection.

Table 10. Final GCM simulations of mean air temperature, precipitation, and ETCCDI indices averaged over the research region between 1971 and 2000 and 2071-2100.

\begin{tabular}{|c|c|c|c|c|c|c|c|c|}
\hline Scenario & Projection & Model & $\Delta \mathrm{T}\left({ }^{\circ} \mathrm{C}\right)$ & $\Delta \mathbf{P}(\%)$ & $\begin{array}{c}\Delta \text { WSDI } \\
(\%)\end{array}$ & $\begin{array}{c}\Delta \text { CSDI } \\
(\%)\end{array}$ & $\begin{array}{c}\Delta R 99 P \\
(\%)\end{array}$ & $\begin{array}{c}\Delta \mathrm{CDD} \\
(\%)\end{array}$ \\
\hline \multirow{4}{*}{ RCP4.5 } & Wet-Warm & IPSL-CM5A-LR_r3i1p1 & 2.91 & 26.17 & 1575.59 & -96.59 & 182.56 & 12.66 \\
\hline & Wet-Cold & BNU-ESM_r1i1p1 & 0.92 & 42.66 & - & - & - & - \\
\hline & Dry-Warm & CSIRO-Mk3-6-0_r3i1p1 & 3.41 & -8.35 & 2677.96 & -97.48 & 12.57 & -8.31 \\
\hline & Dry-Cold & inmcm4_r1i1p1 & 1.75 & -2.00 & 858.61 & -52.22 & 5.41 & -3.34 \\
\hline \multirow{4}{*}{ RCP8.5 } & Wet-Warm & IPSL-CM5A-LR_r2i1p1 & 5.35 & 56.03 & 1094.01 & -94.79 & 709.70 & 21.26 \\
\hline & Wet-Cold & BNU-ESM_r1ī1p1 & 2.69 & 53.69 & - & - & - & - \\
\hline & Dry-Warm & CSIRO-Mk3-6-0_r4i1p1 & 5.58 & -11.70 & 3525.97 & -99.98 & 37.83 & -13.58 \\
\hline & Dry-Cold & GFDL-ESM2G_r1i1p1 & 3.91 & -1.40 & 1376.13 & -99.79 & 124.26 & -5.99 \\
\hline
\end{tabular}



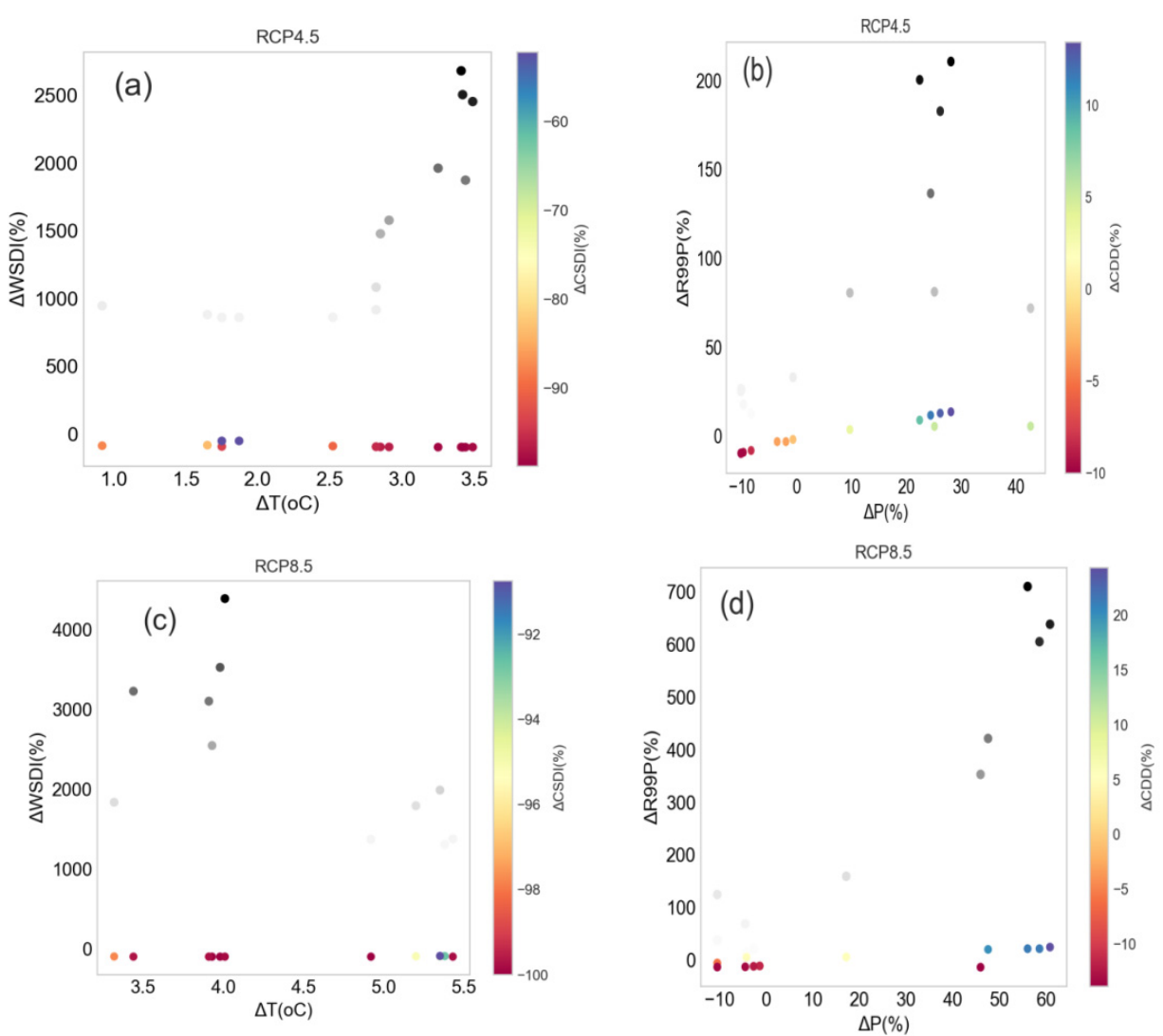

Figure 3. Between 2071-2100 and 1971-2000, changes in mean air temperature (T), warm spell duration index (WSDI), and cold spell duration index (CSDI) are forecast for RCP4.5 (a) and RCP8.5 (c). Between 2071-2100 and 1971-2000, RCP4.5 (b) and RCP8.5 (d) projected changes in annual precipitation sum (P), precipitation due to extremely wet days (R99pTOT), and consecutive dry days (CDD). For the Upper Blue Nile Basin, Table 11 displays a list of selected Climate Models, Experiments, and Ensemble Members.

Table 11. List of selected climate models, experiments, ensemble members for the Upper Blue Nile Basin.

\begin{tabular}{cccccc}
\hline Scenario & Model Name & Institute & Ensembles & References \\
\hline & IPSL-CM5A-LR & Institut Pierre Simon Laplace, Paris, France & r3i1p & [45] \\
\hline BNU-ESM & GCESS, BNU, Beijing, China & r1i1p1 & {$[46]$} \\
\hline CSIRO-Mk3-6-0 & CSIRO Marine and Atmospheric Research & r3i1p1 & {$[47]$} & r1i1p1 & {$[48]$} \\
\hline inmcm4_ & Institute for Numerical Mathematics, Moscow, & r1i1p1 & {$[49,50]$} \\
\hline bCP-csm1-1-m & Beijing Climate Center & r2i1p1 & [45] \\
\hline IPSL-CM5A-LR & Institut Pierre Simon Laplace, Paris, France & r1i1p1 & [46] \\
\hline BNU-ESM_ & GCESS, BNU, Beijing, China & r4i1p1 & [47] \\
\hline CSIRO-Mk3-6-0 & CSIRO Marine and Atmospheric Research & r1i1p1 & [51] \\
\hline GFDL-ESM2G & NOAA Geophysical Fluid Dynamics Laboratory & r3i1p1 & {$[52,53]$} \\
\hline
\end{tabular}

\section{Conclusions}

Identifying the best-performing climate model has provided water resource policymakers with a wealth of knowledge. The envelope-based approach and past performance were applied to the Upper Blue Nile Basin for the selection of representative climate models 
for a climate change impact study. Ten general circulation climate models were chosen for this analysis, five in each representative's climate model, RCP4.5 and RCP8.5, which display medium $4.5 \mathrm{~W} / \mathrm{m}^{2}$ and maximum $8.5 \mathrm{~W} / \mathrm{m}^{2}$ energy released into the atmosphere, respectively. All ensemble members of the 105 and 78 recommended general circulation models by the IPCC 5th assessment report for RCP4.5 and RCP8.5, respectively, were considered to choose the better performing model for the Upper Blue Nile Basin. Three basic screening measures were used: change in the climatic mean, change in the extreme climatic variable, and past performance. Using the change in climatic mean, 20 models were chosen, 5 from each corner. Twenty-five models, including the 50th percentile of the climatic mean, were also screened using change extreme climatic variable, leaving ten models with overall weighted rank. The precipitation has shown a $42.66 \%$ maximum increase in the wet cold corner in model BNU-ESM ensemble member r1i1p1, and a 10.22\% decrease in the dry corner in model CISRO-Mk3-6-0 ensemble member r8i1p1 for RCP4.5. In the dry cold and dry warm corners, precipitation has to show a decreasing rate in all models for RCP4.5; in the case of RCP8.5, precipitation increased by $60.83 \%, 58.57 \%$ and $56.03 \%$ inthea wet warm corner in IPS1-CM5A-LR for ensemble members r1i1p1, r2i1p1, and r3i1p1, respectively; also, the temperature increased by $5.58{ }^{\circ} \mathrm{C}$ in the dry warm corner in the model CISRO-Mk3-6-0 ensemble member r4i1p1.

Author Contributions: Conceptualization, H.W.T. and A.G.; methodology, H.W.T. and A.G.; data curation, H.W.T.; writing-original draft preparation, H.W.T.; writing-review and editing, A.G., D.H. and F.S.; supervision, A.G., D.H. and F.S. All authors have read and agreed to the published version of the manuscript.

Funding: This research was part of the DAAD-EECBP Home Grown PhD Scholarship Program, 2017(57375975) and The APC was funded by the German Research Foundation (DFG) and the Open Access Publication Fund of the University of Rostock/ University Medicine Rostock.

Institutional Review Board Statement: Not applicable.

Informed Consent Statement: Not applicable.

Data Availability Statement: The data used in this study are available from the authors on reasonable request.

Acknowledgments: Hailu Wondmageghu Tenfie thanks the German Academic Exchange Service (DAAD) for providing a scholarship during the study and is appreciative of the financial support from the German Research Foundation (DFG) and the Open Access Publication Fund of the University of Rostock/ University Medicine Rostock.

Conflicts of Interest: The authors declare no conflict of interest.

\section{References}

1. Taylor, K.E.; Stouffer, R.J.; Meehl, G.A. An overview of CMIP5 and the experiment design. Bull. Am. Meteorol. Soc. 2012, 93, 485-498. [CrossRef]

2. Baede, A.; van der Linden, P.; Verbruggen, A. Annex to IPCC Fourth Assessment Report. IPCC Fourth Assess. Rep. 2007, 75-104.

3. van Vuuren, D.P.; Edmonds, J.; Kainuma, M.; Riahi, K.; Thomson, A.; Hibbard, K.; Hurtt, G.C.; Kram, T.; Krey, V.; Lamarque, J.F.; et al. The representative concentration pathways: An overview. Clim. Chang. 2011, 109, 5-31. [CrossRef]

4. Bjørnæs, C. A Guide to Representative Concentration Pathways History of Scenarios Year Name Used in 1990 SA90 First Assessment Report 1992 IS92 Second Assessment Report 2000 SRES—Special Report on Emissions and Scenarios Third and Four Assessment Report 2009 RCP. 2010. Available online: https://mpimet.mpg.de/fileadmin/communication/Im_Fokus/2013 /IPCC_2013/uk_ipcc_A_guide_to_RCPs.pdf. (accessed on 22 February 2021).

5. Jubb, A.I.; Canadell, P.; Dix, M. Representative Concentration Pathways (RCPs). Aust. Clim. Chang. Sci. Progr. $2013,5-7$.

6. Lutz, A.F.; ter Maat, H.W.; Biemans, H.; Shrestha, A.B.; Wester, P.; Immerzeel, W.W. Selecting representative climate models for climate change impact studies: An advanced envelope-based selection approach. Int. J. Climatol. 2016, 36, 3988-4005. [CrossRef]

7. Chen, J.; Brissette, F.P.; Leconte, R. Uncertainty of downscaling method in quantifying the impact of climate change on hydrology. J. Hydrol. 2011, 401, 190-202. [CrossRef]

8. Chen, J.; Brissette, F.P.; Chaumont, D.; Braun, M. Performance and uncertainty evaluation of empirical downscaling methods in quantifying the climate change impacts on hydrology over two North American river basins. J. Hydrol. 2013, 479, 200-214. [CrossRef] 
9. Pryor, S.C.; Barthelmie, R.J.; Clausen, N.E.; Drews, M.; MacKellar, N.; Kjellström, E. Analyses of possible changes in intense and extreme wind speeds over northern Europe under climate change scenarios. Clim. Dyn. 2012, 38, 189-208. [CrossRef]

10. Pour, S.H.; Shahid, S.; Chung, E.S.; Wang, X.J. Model output statistics downscaling using support vector machine for the projection of spatial and temporal changes in rainfall of Bangladesh. Atmos. Res. 2018, 213, 149-162. [CrossRef]

11. Nikiema, P.M.; Sylla, M.B.; Ogunjobi, K.O.; Kebe, I.; Gibba, P.; Giorgi, F.; Omondi, C.K.; Huth, R.; Beck, C.; Philipp, A.; et al. Comparison of a very-fine-resolution GCM with RCM dynamical downscaling in simulating climate in China. J. Hydrol. 2016, 33, 559-570. [CrossRef]

12. Khan, N.; Shahid, S.; Ahmed, K.; Ismail, T.; Nawaz, N.; Son, M. Performance assessment of general circulation model in simulating daily precipitation and temperature using multiple gridded datasets. Water 2018, 10, 1793. [CrossRef]

13. McSweeney, C.F.; Jones, R.G.; Lee, R.W.; Rowell, D.P. Selecting CMIP5 GCMs for downscaling over multiple regions. Clim. Dyn. 2015, 44, 3237-3260. [CrossRef]

14. Khan, A.J.; Koch, M. Selecting and downscaling a set of climate models for projecting climatic change for impact assessment in the Upper Indus Basin (UIB). Climate 2018, 6, 89. [CrossRef]

15. Ahmed, K.; Shahid, S.; Sachindra, D.A.; Nawaz, N.; Chung, E.S. Fidelity assessment of general circulation model simulated precipitation and temperature over Pakistan using a feature selection method. J. Hydrol. 2019, 573, 281-298. [CrossRef]

16. Betrie, G.D.; Mohamed, Y.A.; Van Griensven, A.; Srinivasan, R. Sediment management modelling in the Blue Nile Basin using SWAT model. Hydrol. Earth Syst. Sci. 2011, 15, 807-818. [CrossRef]

17. Conway, D. The climate and hydrology of the Upper Blue Nile river. Geogr. J. 2000, 166, 49-62. [CrossRef]

18. Mohamed, Y.A.; van den Hurk, B.J.J.M.; Savenije, H.H.G.; Bastiaanssen, W.G.M. Hydroclimatology of the Nile: Results from a regional climate model. Hydrol. Earth Syst. Sci. 2005, 9, 263-278. [CrossRef]

19. Roth, V.; Lemann, T.; Zeleke, G.; Subhatu, A.T.; Nigussie, T.K.; Hurni, H. Effects of climate change on water resources in the upper Blue Nile Basin of Ethiopia. Heliyon 2018, 4, e00771. [CrossRef]

20. Taye, M.T.; Willems, P.; Block, P. Implications of climate change on hydrological extremes in the Blue Nile basin: A review. J. Hydrol. Reg. Stud. 2015, 4, 280-293. [CrossRef]

21. Mellander, P.E.; Gebrehiwot, S.G.; Gärdenäs, A.I.; Bewket, W.; Bishop, K. Summer Rains and Dry Seasons in the Upper Blue Nile Basin: The Predictability of Half a Century of Past and Future Spatiotemporal Patterns. PLoS ONE 2013, 8, e68461. [CrossRef]

22. Zaitchik, B.F.; Simane, B.; Habib, S.; Anderson, M.C.; Ozdogan, M.; Foltz, J.D. Building climate resilience in the Blue Nile/Abay Highlands: A role for earth system sciences. Int. J. Environ. Res. Public Health 2012, 9, 435-461. [CrossRef] [PubMed]

23. Sillmann, J.; Kharin, V.V.; Zhang, X.; Zwiers, F.W.; Bronaugh, D. Climate extremes indices in the CMIP5 multimodel ensemble: Part 1. Model evaluation in the present climate. J. Geophys. Res. Atmos. 2013, 118, 1716-1733. [CrossRef]

24. Peterson, T.C.; Folland, C.; Gruza, G.; Hogg, W.; Mokssit, A.; Plummer, N. National Climatic Data Center, National Oceanic and Atmospheric Administration, Asheville, North Carolina, USA, and Chair, WMO Commission for Climatology Open Programme Area Group on the Monitoring and Analysis of Climate Variability and Change. Clim. Chang. Detect. 2001, 54, 143.

25. Weedon, G.P.; Balsamo, G.; Bellouin, N.; Gomes, S.; Best, M.J.; Viterbo, P. The WFDEI meteorological forcing data set: WATCH Forcing data methodology applied to ERA-Interim reanalysis data. Water Resour. Res. 2014, 50, 7505-7514. [CrossRef]

26. Weedon, G.P.; Gomes, S.; Viterbo, P.; Shuttleworth, W.J.; Blyth, E.; ÖSterle, H.; Adam, J.C.; Bellouin, N.; Boucher, O.; Best, M. Creation of the WATCH forcing data and its use to assess global and regional reference crop evaporation over land during the twentieth century. J. Hydrometeorol. 2011, 12, 823-848. [CrossRef]

27. Dee, D.P.; Uppala, S.M.; Simmons, A.J.; Berrisford, P.; Poli, P.; Kobayashi, S.; Andrae, U.; Balmaseda, M.A.; Balsamo, G.; Bauer, P.; et al. The ERA-Interim reanalysis: Configuration and performance of the data assimilation system. Q. J. R. Meteorol. Soc. 2011, 137, 553-597. [CrossRef]

28. Schneider, U.; Becker, A.; Finger, P.; Meyer-Christoffer, A.; Ziese, M.; Rudolf, B. GPCC's new land surface precipitation climatology based on quality-controlled in situ data and its role in quantifying the global water cycle. Theor. Appl. Climatol. 2014, 115, 15-40. [CrossRef]

29. Beaumont, L.J.; Hughes, L.; Pitman, A.J. Why is the choice of future climate scenarios for species distribution modelling important? Ecol. Lett. 2008, 11, 1135-1146. [CrossRef]

30. Wayne, G.P. Representative Concentration Pathways. Available online: https://skepticalscience.com/docs/RCP_Guide.pdf. (accessed on 22 February 2021).

31. Riahi, K.; Rao, S.; Krey, V.; Cho, C.; Chirkov, V.; Fischer, G.; Kindermann, G.; Nakicenovic, N.; Rafaj, P. RCP 8.5-A scenario of comparatively high greenhouse gas emissions. Clim. Chang. 2011, 109, 33-57. [CrossRef]

32. Thomson, A.M.; Calvin, K.V.; Smith, S.J.; Kyle, G.P.; Volke, A.; Patel, P.; Delgado-Arias, S.; Bond-Lamberty, B.; Wise, M.A.; Clarke, L.E.; et al. RCP4.5: A pathway for stabilization of radiative forcing by 2100. Clim. Chang. 2011, 109, 77-94. [CrossRef]

33. van Vuuren, D.P.; Stehfest, E.; den Elzen, M.G.J.; Kram, T.; van Vliet, J.; Deetman, S.; Isaac, M.; Goldewijk, K.K.; Hof, A.; Beltran, A.M.; et al. RCP2.6: Exploring the possibility to keep global mean temperature increase below $2{ }^{\circ} \mathrm{C}$. Clim. Chang. 2011, 109, 95-116. [CrossRef]

34. van Vuuren, D.P.; Stehfest, E.; den Elzen, M.G.J.; van Vliet, J.; Isaac, M. Exploring IMAGE model scenarios that keep greenhouse gas radiative forcing below $3 \mathrm{~W} / \mathrm{m}^{2}$ in 2100. Energy Econ. 2010, 32, 1105-1120. [CrossRef]

35. Wilby, R.L.; Dawson, C.W.; Murphy, C.; O'Connor, P.; Hawkins, E. The Statistical DownScaling Model -Decision Centric (SDSM-DC): Conceptual basis and applications. Clim. Res. 2014, 61, 251-268. [CrossRef]

36. Pielke, R.A.; Wilby, R.L. Regional climate downscaling: What's the point? Eos 2012, 93, 52-53. [CrossRef] 
37. Immerzeel, W.W.; Pellicciotti, F.; Bierkens, M.F.P. Rising river flows throughout the twenty-first century in two Himalayan glacierized watersheds. Nat. Geosci. 2013, 6, 742-745. [CrossRef]

38. Sorg, A.; Huss, M.; Rohrer, M.; Stoffel, M. The days of plenty might soon be over in glacierized Central Asian catchments. Environ. Res. Lett. 2014, 9, 104018. [CrossRef]

39. Murray, V.; Ebi, K.L. IPCC Special Report on Managing the Risks of Extreme Events and Disasters to Advance Climate Change Adaptation (SREX). J. Epidemiol. Community Health 2012, 66, 759-760. [CrossRef]

40. Perkins, S.E.; Pitman, A.J.; Holbrook, N.J.; McAneney, J. Evaluation of the AR4 climate models' simulated daily maximum temperature, minimum temperature, and precipitation over Australia using probability density functions. J. Clim. 2007, 20, 4356-4376. [CrossRef]

41. Sáanchez, E.; Romera, R.; Gaertner, M.A.; Gallardo, C.; Castro, M. A weighting proposal for an ensemble of regional climate models over Europe driven by 1961-2000 ERA40 based on monthly precipitation probability density functions. Atmos. Sci. Lett. 2009, 10, 241-248. [CrossRef]

42. Kjellström, E.; Boberg, F.; Castro, M.; Christensen, J.H.; Nikulin, G.; Sánchez, E. Daily and monthly temperature and precipitation statistics as performance indicators for regional climate models. Clim. Res. 2010, 44, 135-150. [CrossRef]

43. Chen, J.; Brissette, F.P.; Lucas-Picher, P.; Caya, D. Impacts of weighting climate models for hydro-meteorological climate change studies. J. Hydrol. 2017, 549, 534-546. [CrossRef]

44. Bhaskar, R.; Srinivas, D.; Ratna, S.B. Development of a high resolution daily gridded temperature data set (1969-2005) for the Indian region. Atmos. Sci. Lett. 2009, 10, 249-254. [CrossRef]

45. Dufresne, J.L.; Foujols, M.A.; Denvil, S.; Caubel, A.; Marti, O.; Aumont, O.; Balkanski, Y.; Bekki, S.; Bellenger, H.; Benshila, R.; et al. Climate Change projections Using the IPSL-CM5 Earth System Model: From CMIP3 to CMIP5; Climate Dynamics: Paris, France, 2013; Volume 40, ISBN 0038201216.

46. Ji, D.; Wang, L.; Feng, J.; Wu, Q.; Cheng, H.; Zhang, Q.; Yang, J.; Dong, W.; Dai, Y.; Gong, D.; et al. Description and basic evaluation of Beijing Normal University Earth System Model (BNU-ESM) version 1. Geosci. Model Dev. 2014, 7, 2039-2064. [CrossRef]

47. Rotstayn, L.D.; Collier, M.A.; Dix, M.R.; Feng, Y.; Gordon, H.B.; O’Farrell, S.P.; Smith, I.N.; Syktus, J. Improved simulation of Australian climate and ENSO-related rainfall variability in a global climate model with an interactive aerosol treatment. Int. J. Climatol. 2010, 30, 1067-1088. [CrossRef]

48. Volodin, E.M.; Dianskii, N.A.; Gusev, A.V. Simulating present-day climate with the INMCM4.0 coupled model of the atmospheric and oceanic general circulations. Izv. Atmos. Ocean Phys. 2010, 46, 414-431. [CrossRef]

49. Wu, T.; Li, W.; Ji, J.; Xin, X.; Li, L.; Wang, Z.; Zhang, Y.; Li, J.; Zhang, F.; Wei, M.; et al. Global carbon budgets simulated by the Beijing Climate Center Climate System Model for the last century. J. Geophys. Res. Atmos. 2013, 118, 4326-4347. [CrossRef]

50. Xin, X.G.; Wu, T.W.; Zhang, J. Introduction of CMIP5 experiments carried out with the climate system models of Beijing climate center. Adv. Clim. Chang. Res. 2013, 4, 41-49. [CrossRef]

51. Rotstayn, L.D.; Jeffrey, S.J.; Collier, M.A.; Dravitzki, S.M.; Hirst, A.C.; Syktus, J.I.; Wong, K.K. Aerosol- and greenhouse gasinduced changes in summer rainfall and circulation in the Australasian region: A study using single-forcing climate simulations. Atmos. Chem. Phys. 2012, 12, 6377-6404. [CrossRef]

52. Arora, V.K.; Scinocca, J.F.; Boer, G.J.; Christian, J.R.; Denman, K.L.; Flato, G.M.; Kharin, V.V.; Lee, W.G.; Merryfield, W.J. Carbon emission limits required to satisfy future representative concentration pathways of greenhouse gases. Geophys. Res. Lett. 2011, 38, 3-8. [CrossRef]

53. Von Salzen, K.; Scinocca, J.F.; McFarlane, N.A.; Li, J.; Cole, J.N.S.; Plummer, D.; Verseghy, D.; Reader, M.C.; Ma, X.; Lazare, M.; et al. The Canadian fourth generation atmospheric global climate model (CanAM4). Part I: Representation of physical processes. Atmos. Ocean 2013, 51, 104-125. [CrossRef] 